\title{
Sema4D/CD100 Deficiency Leads to Superior Performance in Mouse Motor Behavior
}

\author{
Kazunori Yukawa, Tetsuji Tanaka, Noriko Takeuchi, Hiroyuki Iso, \\ Li Li, Akira Kohsaka, Hidefumi Waki, Masayasu Miyajima, \\ Masanobu Maeda, Hitoshi Kikutani, Atsushi Kumanogoh
}

\begin{abstract}
Background: Sema4D/CD100 is a type of class 4 semaphorin, exhibiting crucial roles in growth cone guidance in developing neurons. Sema4D is widely expressed throughout the central nervous system in embryonic mouse brain, and is selectively localized to oligodendrocytes and myelin in the postnatal brain. However, direct evidence of the actual involvement of Sema4D in the neuronal network development crucial for neurobehavioral performance is still lacking. The present study therefore examined whether Sema4D deficiency leads to abnormal behavioral development. Methods: Both wild-type and Sema4D-deficient mice were subjected to behavioral analyses including open-field, adhesive tape removal, rotarod tests and a water maze task. Results: Open-field tests revealed increased locomotor activity in Sema4D-deficient mice with less percentage of time spent in the center of the field. In both the adhesive tape removal and rotarod tests, which examine motor coordination and balance, Sema4D-deficient mice showed significantly superior performance, suggesting facilitated motor behavior. Both Sema4D-deficient and wild-type mice successfully learnt the water maze task, locating a hidden escape platform, and also showed precise memory for the platform position in probe tests. However, the swimming speed of Sema4D-deficient mice was significantly faster than that of wild-type mice, providing further evidence of their accelerated motor behavior. Conclusion: Our mouse behavioral analyses revealed enhanced motor activity in Sema4D-deficient mice, suggesting the crucial involvement of Sema4D in the neurodevelopmental processes of the central structures mediating motor behavior in mice.
\end{abstract}

RÉSUMÉ: Performance supérieure du comportement moteur chez la souris ayant un déficit en Sema4D/CD100. Contexte : Sema4D/CD100 est un type de sémaphorine de classe 4 qui joue des rôles cruciaux dans le guidage des cônes de croissance dans les neurones en développement. Sema4D est largement exprimé dans tout le système nerveux central de l'embryon chez la souris et il est localisé sélectivement aux oligodendrocytes et à la myéline du cerveau après la naissance. Cependant, il n'y a pas de preuve directe de l'implication de Sema4D dans le développement du réseau neuronal qui est crucial pour le fonctionnement neurocomportemental. Dans cette étude, nous avons examiné si un déficit en Sema4D entraîne un développement comportemental anormal. Méthodes : Des souris de phénotype sauvage et des souris déficientes en Sema4D ont été soumises à des analyses comportementales, dont le test du champ ouvert, de l'adhesive tape removal, du rotarod et du labyrinthe aqueux. Résultats : Les tests de champ ouvert ont montré que les souris ayant un déficit en Sema4D avaient une activité locomotrice accrue et passaient un pourcentage moindre du temps dans le centre du champ. Dans les tests de l'adhesive tape removal et du rotarod, qui évaluent la coordination motrice et l'équilibre, les souris ayant un déficit en Sema4D ont présenté une performance significativement supérieure, ce qui est en faveur d'un comportement moteur facilité. Les souris ayant un déficit en Sema4D et les souris de type sauvage ont appris avec succès la tâche du labyrinthe aqueux qui consistait à localiser une plate-forme de sauvetage dissimulée et ont également fait preuve d'une mémoire précise de la position de la plate-forme lorsque le test était répété après avoir retiré la plate-forme. De plus, la vitesse de nage des souris ayant un déficit en Sema4D était significativement supérieure à celle des souris de type sauvage, ce qui est en faveur d'un comportement moteur accéléré. Conclusion : Nos analyses comportementales chez la souris ont démontré que les souris ayant un déficit en Sema4D ont une activité motrice accrue, ce qui est en faveur du rôle crucial que joue Sema4D dans le processus de développement nerveux des structures centrales, soit un rôle facilitant sur le comportement moteur chez la souris.

Can. J. Neurol. Sci. 2009; 36: 349-355

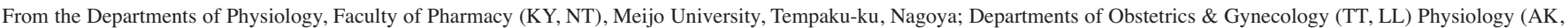

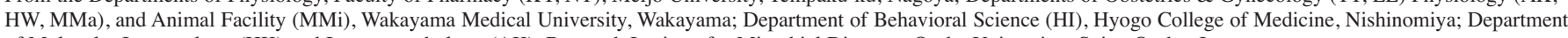
of Molecular Immunology (HK) and Immunopathology (AK), Research Institute for Microbial Diseases, Osaka University, Suita, Osaka, Japan.

Received September 7, 2007. Final Revisions Submitted December 15, 2008.

Correspondence to: Kazunori Yukawa, Department of Physiology, Faculty of Pharmacy, Meijo University, 150 Yagotoyama, Tempaku-ku, Nagoya 468-8503, Japan. 
Semaphorins comprise a large family of phylogenetically conserved soluble and transmembrane molecules that are encoded by a large gene family divided into eight classes ${ }^{1}$. Semaphorins were originally identified as repulsive axon guidance cues involved in induction of growth cone collapse in developing neurons ${ }^{2-4}$. Later studies also found widespread roles in a variety of developmental and pathological conditions ${ }^{5,6}$. Sema4D, a class 4 semaphorin, has facilitated our understanding of how semaphorin signals regulate the cytoskeletal changes that mediate repulsion ${ }^{7-10}$. Sema4D, also known as CD100, induces repulsive changes such as growth cone collapse in cultured hippocampal neurons and retinal ganglion cells ${ }^{7}$. For this repulsion, Sema4D binds to PlexinB1, a member of the plexin family, a predominant group of semaphorin receptors ${ }^{7}$. Both Sema4D and PlexinB1 contain a distinctively conserved Sema domain of $\sim 400$ amino acids, featuring a seven-blade $\beta$-propeller fold in their respective extracellular domains ${ }^{1,3}$. Sema4D and PlexinB1 interact with each other through their respective Sema domains $^{5}$. In the intracellular region, PlexinB1 has two GTPase activating protein (GAP) domains segmented by a GTPase binding domain and a PDZ-binding site at the $\mathrm{C}$ terminal ${ }^{5,7,8}$. Binding of Sema4D to PlexinB1 induces clustering of the PlexinB1 receptors, leading to activation of GAP activities also facilitated by active GTPase and Rnd1-dependent relief of GAP domain interaction ${ }^{8}$. PlexinB1 GAP activity promotes conversion from GTP-bound (active) R-Ras to GDP-bound (inactive) R-Ras, resulting in downregulation of R-Ras activity, which causes a decrease in integrin-based cell adhesion to the extracellular matrix, and subsequently, growth cone collapse in cultured hippocampal neurons ${ }^{8}$. PlexinB1 also allows the intracellular RhoA-specific guanine nucleotide exchange factors (GEF) PDZ-RhoGEF and leukemia-associated RhoGEF (LARG) to bind to the PDZ-binding motif at the $\mathrm{C}$ terminal of PlexinB $1^{7}$. Sema4D binding to PlexinB1 stimulates the GEF activities of PDZ-RhoGEF and LARG, promoting conversion from the GDP-bound form to the GTP-bound form of RhoA, a Rho GTPase crucial for the regulation of actin and microtubule dynamics $^{7}$. The increase in GTP-bound RhoA functions to enhance actomyosin contractility through Rho kinase activation and myosin light chain phosphorylation, thereby leading to growth cone collapse of hippocampal neurons ${ }^{5,7}$. Thus, both RRas GAP activity and PDZ-RhoGEF-mediated RhoA activation by plexin-B1 are necessary for Sema4D-induced growth cone collapse of cultured hippocampal neurons ${ }^{7,8}$.

The crucial roles of Sema4D in growth cone guidance have been demonstrated in many studies using primary neurons in culture, suggesting involvement in the control of neuronal wiring in vivo ${ }^{7-10}$. A recent RNAi-based approach revealed that Sema4D is required for GABAergic synapse development in hippocampal neurons ${ }^{11}$. However, direct evidence that Sema4D is actually involved in the development of the functional neuronal network necessary for the regulation of neurobehavioral performance is still lacking. To gain insight into whether Sema4D is involved in the formation of the neuronal networks controlling mouse behavior, we subjected Sema4D-deficient mice to a series of mouse behavioral analyses. The results revealed accelerated motor activities in Sema4D-deficient mice in several of the behavioral tests.

\section{Materials ANd Methods}

Sema4D-deficient mice: Mice deficient in Sema4D were generated by gene targeting of E14.1 embryonic stem (ES) cells $^{12}$. Briefly, targeting vectors were designed to replace the exon containing the initiation codon with a neomycin-resistance gene then introduced into E14.1 Embryonic stem cells using electroporation. Clones resistant to G418 and ganciclovir were screened by PCR and confirmed by Southern blot analysis. Mutant ES cells were injected into blastocysts (C57BL/6) then transferred into the uteri of pseudopregnant mice to generate chimeras. The chimeras were bred with C57BL/6 mice for germline transmission of the mutant allele. Pairs of resultant heterozygous mice were subsequently bred to obtain homozygous Sema4D-deficient mice. The resulting mice were backcrossed with C57BL/6 mice. The present study used F9 generation knockout mice (three to four months old), with their wild-type littermates as controls. The mice were housed in the animal facilities of Wakayama Medical University. The care and sacrifice of animals and the experiment protocols were performed according to the guidelines promulgated by the Physiological Society of Japan and the guidelines on animal experiments of Wakayama Medical University. Our institutional Animal Ethics Review committee approved the experimental protocol.

Immunoblotting: For Western blot analysis, tissue extracts were prepared from mouse brain containing cerebellum. Twenty micrograms of each sample were adjusted to give a final solution of $60 \mathrm{mM}$ Tris- $\mathrm{HCl}$ (pH 6.8), 2\% SDS, 10\% glycerol, $0.1 \%$ bromophenol blue and $5 \% \beta$-mercaptoethanol. This solution was then heated at $100^{\circ} \mathrm{C}$ for $5 \mathrm{~min}$, electrophoresed through a $10 \%$ SDS-polyacrylamide gel, and transferred to polyvinylidine difluoride membranes (Amersham Pharmacia Biotech, Buckinghamshire, UK). Sema4D was detected with CD100 antibody (BD Transduction Laboratories, NJ, USA) using an ECL-plus Western blot detection system in accordance with the manufacturer's instructions (Amersham).

Calbindin-staining: Wild-type $(\mathrm{n}=4)$ and Sema4D-deficient littermates $(n=5)$ were anesthetized and perfused intracardially with $4 \%$ paraformaldehyde. Four millimeter-thick coronary sections containing cerebellum and brain stem were prepared with the acrylic mouse coronal brain matrices (ROBOZ SURGICAL, Gaithersburg, MD) and post-fixed in $4 \%$ paraformaldehyde solution overnight at $4^{\circ} \mathrm{C}$. They were then equilibrated in a gradually increasing concentration of sucrose solution $(12,15,18,20,25$ and $30 \%)$ in PBS at $4^{\circ} \mathrm{C}$. Once equilibrated, tissues were mounted in Tissue-Tek O.C.T. compound and cut into 25 - $\mu$ m-thick coronal sections on a cryostat (Leica). To detect calbindin in the cerebellum, tissue sections were treated in $10 \mathrm{mM}$ sodium citrate buffer ( $\mathrm{pH} \mathrm{6.0)}$ and placed in a microwave oven for antigen unmasking. After blocking, tissue sections were incubated with a rabbit antibody recognizing calbindin (Chemicon International, Temecula, CA, USA) at $4^{\circ} \mathrm{C}$ overnight. Sections were then incubated with peroxidase-labeled polymer conjugated to goat anti-rabbit immunoglobulin (DakoCytomation, Kyoto, Japan), and Purkinje cells with calbindin were visualized in situ according to the DAB detection procedure. Pictures were taken at a magnification of $400 \times$ using a light microscope equipped with a 3CCD camera (HV-C20S; Nikon, Tokyo, Japan). 
Footprint analysis: The footprint test was performed to compare the gait of Sema4D-deficient mice $(n=10)$ with that of wild-type controls $(n=10)$. The hind- and forefeet were coated with black and red nontoxic paint, respectively. The mice were then allowed to walk along a 50-cm-long 10-cm-wide runway covered with a sheet of white paper. Stride length, hind-base width, front-base width and distance from left or right hind footprints were measured following as previously reported ${ }^{13}$.

Open-field test: Each mouse was placed in a circular openfield area (diameter: $80 \mathrm{~cm}$ ) and allowed to freely explore the environment for 20 minutes. The horizontal activities of 19 male wild-type and 18 male Sema4D-deficient mice were measured using a computer-assisted video tracking system (CompACT vas; Muromachi Kikai, Tokyo, Japan).

Home cage locomotor activity: Mice (ten wild-type and eight Sema4D-deficient mice) were individually housed in a standard home cage and acclimated for 48 hours. Home cage activity was monitored over 24 hours using the SUPERMEX system with a passive-type infrared ray sensor (Muromachi Kikai, Tokyo).

Elevated plus-maze test: The elevated plus-maze test was conducted using nine wild-type and eight Sema4D-deficient mice following a previously established method ${ }^{14}$. Time spent in the closed and open arms, and entry into the open and closed arms were measured using a computer-assisted video tracking system (CompACT vas; Muromachi Kikai, Tokyo, Japan).

Light/dark exploration test: The light-dark exploration test was conducted using ten wild-type and eight Sema4D-deficient mice as previously reported ${ }^{14}$. Time spent and full-body transitions into the light compartments, and total full-body transitions between the light and dark compartments were measured by applying a computer-assisted video tracking system (CompACT vas; Muromachi Kikai, Tokyo, Japan).

Prepulse inhibition of the acoustic startle response: Prepulse inhibition of acoustic startle responses was measured using 14 male wild-type and 19 male Sema4D-deficient mice with the SR-Lab System (San Diego Instruments, San Diego, CA, USA) as previously described ${ }^{15}$. A test session was initiated by placing a mouse in the plexiglas cylinder to which it was acclimated for five minutes. A test session was composed of seven trial types. A $40-\mathrm{msec}, 120 \mathrm{~dB}$ sound burst was used as the startle stimulus. The present study used five different acoustic prepulses plus auditory startle stimulus trials. The prepulse sound preceded the onset of the startle stimulus by $100 \mathrm{msec}$. The 20 -msec prepulse sounds were $74,78,82,86$, or $90 \mathrm{~dB}$. Additionally, in some trials no stimulus was presented to measure base-line movement in the cylinders. Six blocks of seven trial types were presented in a pseudorandom manner such that each trial type was presented once within a block. The mean intertrial interval was set at $15 \mathrm{sec}$ (ranging from 10 to $25 \mathrm{sec}$ ). The startle response was recorded for $160 \mathrm{msec}$ (measuring the response every $1 \mathrm{msec}$ ) starting with onset of the startle stimulus. The background noise level in each chamber was $69 \mathrm{~dB}$. The maximum startle amplitude recorded during the 160 -msec sampling window was used as the dependent variable. Percent prepulse inhibition of a startle response was calculated as: 100-[(startle response on acoustic prepulse plus startle stimulus trials/startle response alone trials) $x$ 100]. Acoustic response amplitude data were analyzed using the Student's $t$-test. Prepulse inhibition data were analyzed with two-way (genotype $\times$ prepulse sound level) ANOVA with repeated measures.
Adhesive tape removal test: The adhesive tape removal task involved 20 wild-type and 16 Sema4D-deficient mice, and was performed following the protocol described by others ${ }^{16}$. Adhesive tape of five sizes $(0.625,0.5,0.375,0.25,0.125$ inches ${ }^{2}$ ) was attached to the forehead in the above order. In response, mice raised both forepaws and attempted to remove the tape. Each trial was given a score equal to the size of the largest tape the mouse was unable to remove within $60 \mathrm{sec}$ ( 5 to 1 , a higher score equals a worse performance). Results represented the average from two trials.

Rotarod test: The rotarod test for motor coordination involved 14 male wild-type and 14 male Sema4D-deficient mice, and was initially performed by placing each mouse on a rotating drum (Ugo Basile; Stoelting, Wood Dale, IL, USA) at $4 \mathrm{rpm}$. The latency to falling off the drum was measured as an index of motor coordination. After one week, each mouse was again placed on the rotating drum and subjected to acceleration from 4 to $20 \mathrm{rpm}$ over a five-minute period. The latency for remaining on the rotating drum was measured as another parameter of motor coordination.

Water maze analysis: Spatial learning and memory were tested in 17 male wild-type and 18 male Sema4D-deficient mice using a Morris water maze consisting of a circular plastic pool (diameter: $120 \mathrm{~cm}$; depth: $25 \mathrm{~cm}$ ). The pool was located in a rectangular room (width: $220 \mathrm{~cm}$; length: $260 \mathrm{~cm}$; height: 240 $\mathrm{cm})$ with numerous visual cues. For swimming tracking, a small TV camera was fixed to the end of a metal rod extending over the pool. Mice were trained to locate a hidden escape platform during two-trial daily sessions conducted over 16 days. In each task, the mice were required to locate and climb onto a hidden circular platform (diameter: $11 \mathrm{~cm}$ ) submerged $1 \mathrm{~cm}$ below the surface of opaque water (temperature of $25 \pm 1^{\circ} \mathrm{C}$ ). The hidden platform was located at the center of a quadrant of the pool; this position was fixed throughout the task. Mice were allowed to search for the platform for $60 \mathrm{sec}$, and the time spent reaching the platform (latency) was recorded. During the probe trial on day 17 , the platform was removed and each mouse was allowed to search for $60 \mathrm{sec}$. Both the quadrant search times and platform crossings were measured post-hoc from videotape recordings of the probe trials. The results were evaluated by ANOVA followed by Dunnett's test for comparison between wild-type and Sema4D-deficient mice.

Novel object recognition test: The object recognition test was performed according to a modified previously reported method ${ }^{17}$. Mice (wild-type: $n=10$, Sema4D-deficient mice: $n=8$ ) were placed in an open field (diameter: $80 \mathrm{~cm}$ ) in which two identical solid impermeable objects were positioned in the center of respective neighboring quadrants. Mice were allowed to explore the area for three min. One hour later, mice were again placed in the same open field with identical objects, which had been cleaned thoroughly with $50 \%$ ethanol, for three minutes. After 24 hours, the mice were again placed in the cleaned field containing one of the original objects and a novel object. Time spent exploring each of the objects was recorded over three minutes. Learning (D score) was calculated as $(A-B) /(A+B)$, where $\mathrm{A}$ is the time spent exploring the novel object and $\mathrm{B}$ is the time spent exploring the familiar object.

Statistics: Statistical analyses were conducted using StatView (Abacus Concepts, Berkeley, CA, USA). Unless otherwise 
specified, data were analyzed by ANOVA and values of $\mathrm{p}<0.05$ were regarded as significant. Values are presented as means \pm SEM.

\section{Results}

\section{Absence of Sema4D protein in the Sema4D-deficient mice brain}

As shown in Figure 1a, Western blotting confirmed the absence of Sema4D protein in the Sema4D-deficient mice brain. Since Sema4D and its receptor plexin-B1 are abundant in mouse cerebellum ${ }^{18-20}$, we characterized the motor behavioral phenotype of Sema4D-deficient mice using footprint analysis. There were no significant differences between the two genotypes in stride length, base width or front footprint/hind footprint overlap (Figure 1b, stride length; $\mathrm{F}(1,18)=0.031, \mathrm{p}>0.05$, front limb base width; Student's $t$-test, $\mathrm{p}>0.05$, Hind limb base width; Student's $t$-test, $\mathrm{p}>0.05$, footprint overlap; Student's $t$-test, $\mathrm{p}>0.05$ ). As seen in Figure 1c, calbindin-immunostaining could not detect any obvious differences in calbindin intensity or the number of Purkinje cells. Furthermore, the dendritic arborization of Purkinje cells appeared normal in Sema4D-deficient mice.

\section{Enhanced locomotor activity in Sema4D-deficient mice}

To evaluate the effects of Sema4D gene knockout $(\mathrm{KO})$ on mouse locomotor activity, the horizontal activities of wild-type (WT) and Sema4D-deficient mice in open-field tests were examined. Although the horizontal activities of both types of mice gradually decreased over the four blocks of the test, the extent of activity was significantly higher in Sema4D-deficient mice than in wild-type mice (Figure 2a). The overall difference between the mouse strains and the decrease among time blocks was significant $(\mathrm{F}(1,35)=95.669, \mathrm{p}<0.05$ and $\mathrm{F}(3,105)=42.209$, $\mathrm{p}<0.05$, respectively). A group difference in block interaction was also significant $(\mathrm{F}(3,105)=18.471, \mathrm{p}<0.05)$. A post-hoc test revealed a significant difference between wild-type and Sema4D-deficient mice in each time block. Thus, the open-field tests revealed that Sema4D-deficient mice showed higher locomotor activity than wild-type mice. Sema4D-deficient mice also showed significantly less center time than wild-type controls in the open field (Figure $2 b ; 4.15 \pm 2.89 \%$ versus 9.29
C WT

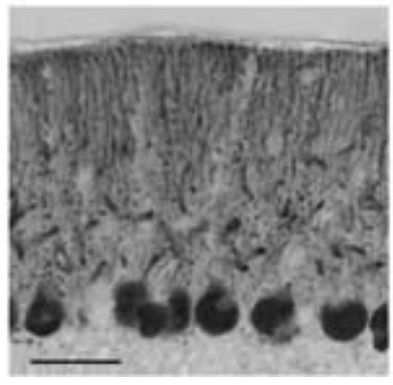

b

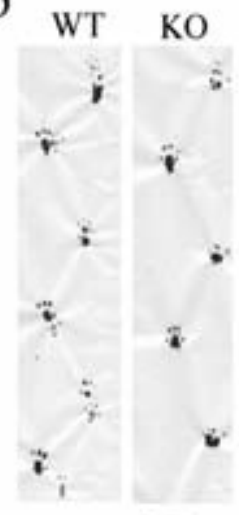

KO

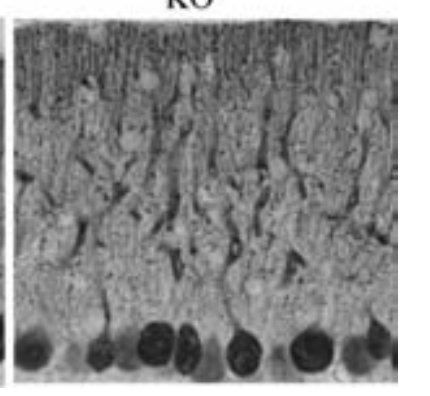

Figure 1: Western blotting analysis demonstrated the absence of Sema4D protein in the Sema4D-deficient mice brain (a). Footprint analysis did not disclose any abnormal gait in Sema4D-deficient mice (b). Calbindin-staining showed no aberrant branching pattern of Purkinje cells in the Sema4D-deficient cerebellum (c). Scale bar, 50 um. $W T=$ wild type; $K O=$ knockout: Sema4D-deficient mice.

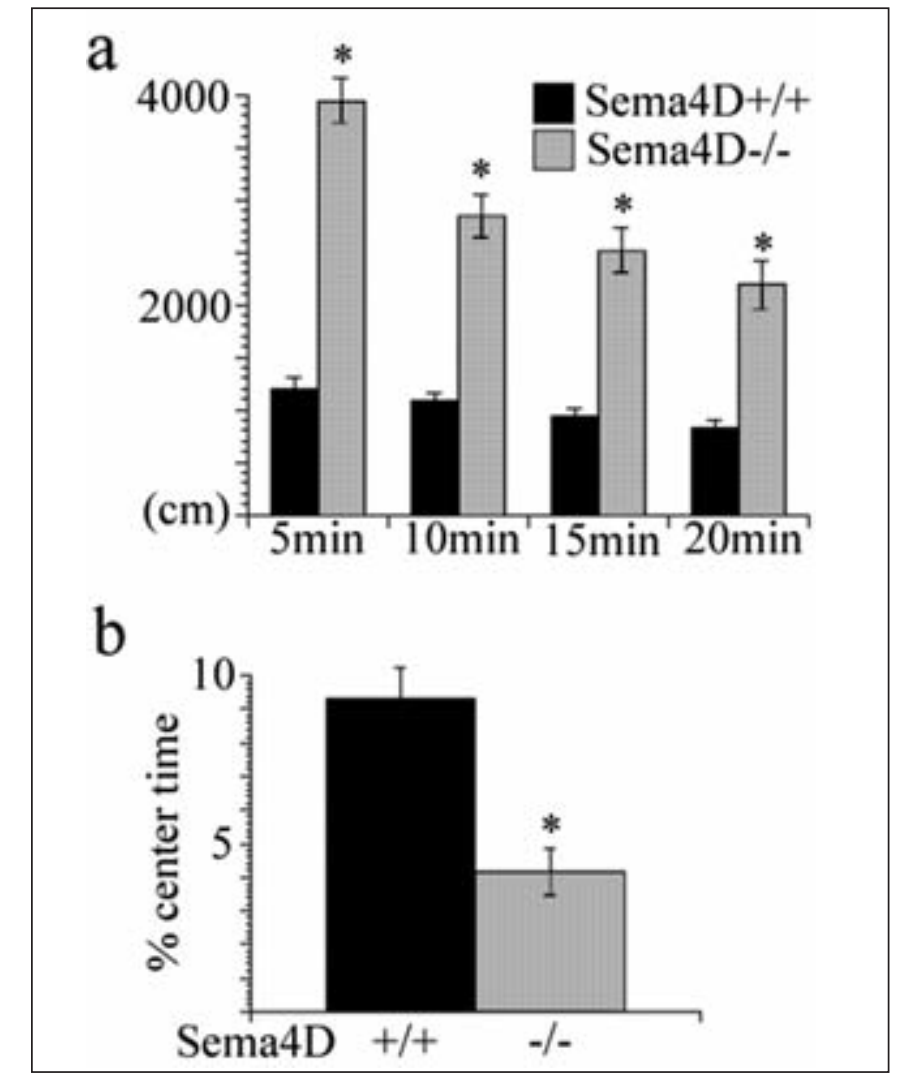

b

Figure 2: Enhanced locomotor activity of Sema4D-deficient mice in open-field tests. Naive animals were exposed to the open-field test and their locomotor activity (moving distance) was monitored for 20 min (5 min/point). Sema4D-deficient mice showed augmented locomotor activity compared with wild-type mice (a). Sema4D-deficient mice also spent a significantly less percentage of time in the center of the field than wild-type controls $(b) .+/+$ : wild-type $(n=19)$; -/-: Sema4D-deficient mice $(n=18)$. 
$\pm 4.24 \%$, Student's $t$-test, $\mathrm{p}<0.05)$. However, there was no significant difference in the feces number produced during the test between the two genotypes (KO versus WT; $3.28 \pm 1.56$ versus $2.47 \pm 2.41$, Student's $t$-test, $\mathrm{p}>0.05$ ). Furthermore, there was no significant effect of genotype on measures of anxietyrelated behavior and general locomotor activity in the elevated plus-maze (\%time in closed arm; KO versus WT; $46.63 \pm 34.07$ $\%$ versus $44.97 \pm 31.37 \%$, Student's $t$-test, $p>0.05$, closed entry; $5.75 \pm 4.59$ versus $7.56 \pm 3.68$, Student's $t$-test, $\mathrm{p}>0.05$, open entry; $7.38 \pm 3.503$ versus $8.33 \pm 4.33$, Student's $t$-test, $\mathrm{p}>0.05$ ). There was also no significant effect of genotype on measures of anxiety-related behavior in the light/dark exploration test $(\%$ time in dark; KO versus WT; $52.24 \pm 27.13$ versus $34.21 \pm 24.23$, Student's t-test, $\mathrm{p}>0.05$, transmission; $11.5 \pm 6.89$ versus $17.9 \pm$ 8.8 , Student's $t$-test, $\mathrm{p}>0.05)$. Furthermore, Sema4D-deficient mice showed normal prepulse inhibition to the acoustic startle $(\mathrm{F}(1,31)=0.602, \mathrm{p}>0.05$, and $\mathrm{F}(4,124)=0.673, \mathrm{p}>0.05)$. Monitoring of locomotor activity for 24 hours in the home cage did not result in any significant differences between the two genotypes $(\mathrm{F}(1,16)=0.29, \mathrm{p}>0.05$, and $\mathrm{F}(16,368)=0.440$, $\mathrm{p}>0.05)$.

\section{Superior performance of Sema4D-deficient mice in both adhesive tape removal and rotarod tests}

To examine the locomotive power of Sema4D-deficient mice, adhesive tape removal and rotarod tests examining motor function were performed. Sema4D-deficient mice exhibited significantly better performance in the adhesive tape removal test than the wild-type controls (Figure $3 \mathrm{a} ; 1.13 \pm 1.71$ versus $2.55 \pm 1.70$, Student's $t$-test, $\mathrm{p}<0.05)$. The rotarod test revealed that Sema4D-deficient mice exhibited significantly longer latencies on the rod at an accelerated speed of rotation than wildtype mice (Figure 3b; $257.79 \pm 211.04$ versus $94.36 \pm 75.29$, Student's $t$-test, $\mathrm{p}<0.05)$. Mean body weight did not differ significantly between wild-type and Sema4D-deficient mice $(36.986 \pm 1.080$ versus $34.779 \pm 0.920 \mathrm{~g}$, Student's $t$-test, $\mathrm{p}>0.05$ ), which excluded the possible influence of body weight on rotarod performance.

\section{Faster swimming speed of Sema4D-deficient mice}

To examine whether Sema4D is involved in spatial learning and memory, wild-type and Sema4D-deficient mice were subjected to Morris water maze tests ${ }^{21}$. The ability of both groups to locate the hidden platform improved significantly $(\mathrm{F}(27,432)=3.404, \mathrm{p}<0.05)$ during the training trials, and there was no significant difference between the two groups (Figure 4a, $\mathrm{F}(1,16)=2.142, \mathrm{p}>0.05)$. In the probe test, both wild-type and Sema4D-deficient mice spent more time in the target quadrant than any other quadrant (Figure $4 b, F(3,48)=9.888$, p $<0.05$ ), and again there was no significant difference between the two groups ( $p>0.05$, Dunnett's test). Thus, Sema4D-deficient mice showed normal learning and memory for the platform position in the water maze. However, measurement of swimming speed revealed that Sema4D-deficient mice swam significantly faster than wild-type mice (Figure 4c; wild-type mice, $24.9 \pm 1.71 \mathrm{~cm} / \mathrm{s}$ vs. Sema4D-deficient mice, $33.8 \pm 2.52 \mathrm{~cm} / \mathrm{s}, \mathrm{p}<0.05$, Student's $t$ test). The novel object recognition test detected no significant difference in memory between Sema4D-deficient mice and wildtype controls $(0.38 \pm 0.70$ versus $0.40 \pm 0.65$, Student's $t$-test, $\mathrm{p}>0.05)$.

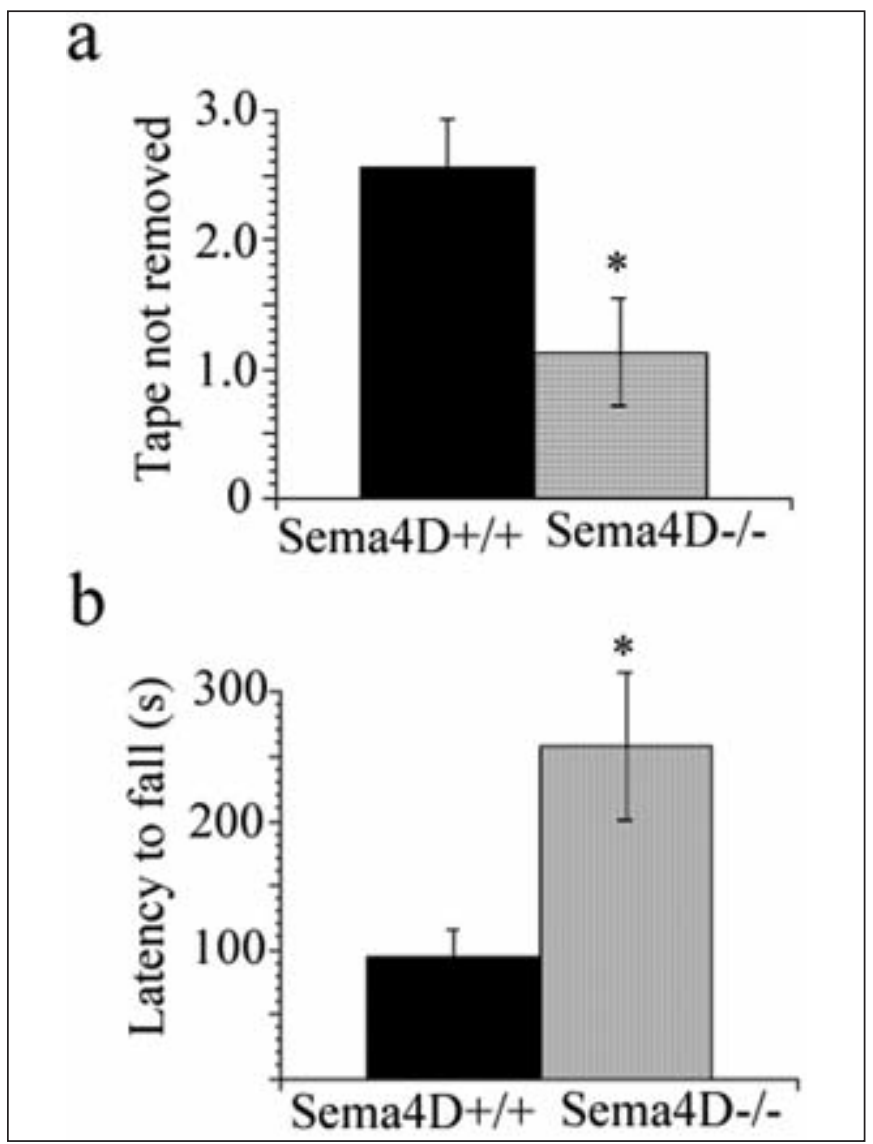

Figure 3: Superior performance of Sema4D-deficient mice in both adhesive tape removal and rotarod tests. Sema4D-deficient mice exhibited significantly superior performance in the adhesive tape removal test compared with wild-type controls (a). Sema4D-deficient mice acquired significantly longer latencies in an accelerated version of the rotarod test (b). +/+: wild-type; -/-: Sema4D-deficient mice. ${ }^{*} p<0.05$, Student's $t$-test.

\section{Discussion}

Our mouse behavioral analyses revealed enhanced motor activity in Sema4D-deficient mice in open field, adhesive tape removal, rotarod and Morris water maze tests. These findings therefore suggest crucial roles of semaphorins in the developmental processes of the internal system regulating mouse motor behavior.

The enhanced activity of Sema4D-deficient mice in the open field, adhesive tape removal and rotarod tests, and swimming in the water maze may be due to abnormal neuronal organization of the basal ganglia or cerebellum generated in the mutant mice. Semaphorins play crucial roles as repulsive or attractive axon guidance molecules during the construction of the neuronal network in central nervous system (CNS) development ${ }^{5}$. Even though calbindin-stained Purkinje cells did not disclose any obvious abnormal phenotype, Sema4D is widely expressed throughout the CNS and Sema4D receptors plexin-B1 and CD72 are localized in mouse cerebellum ${ }^{18,19,22-25}$. Thus, the absence of 


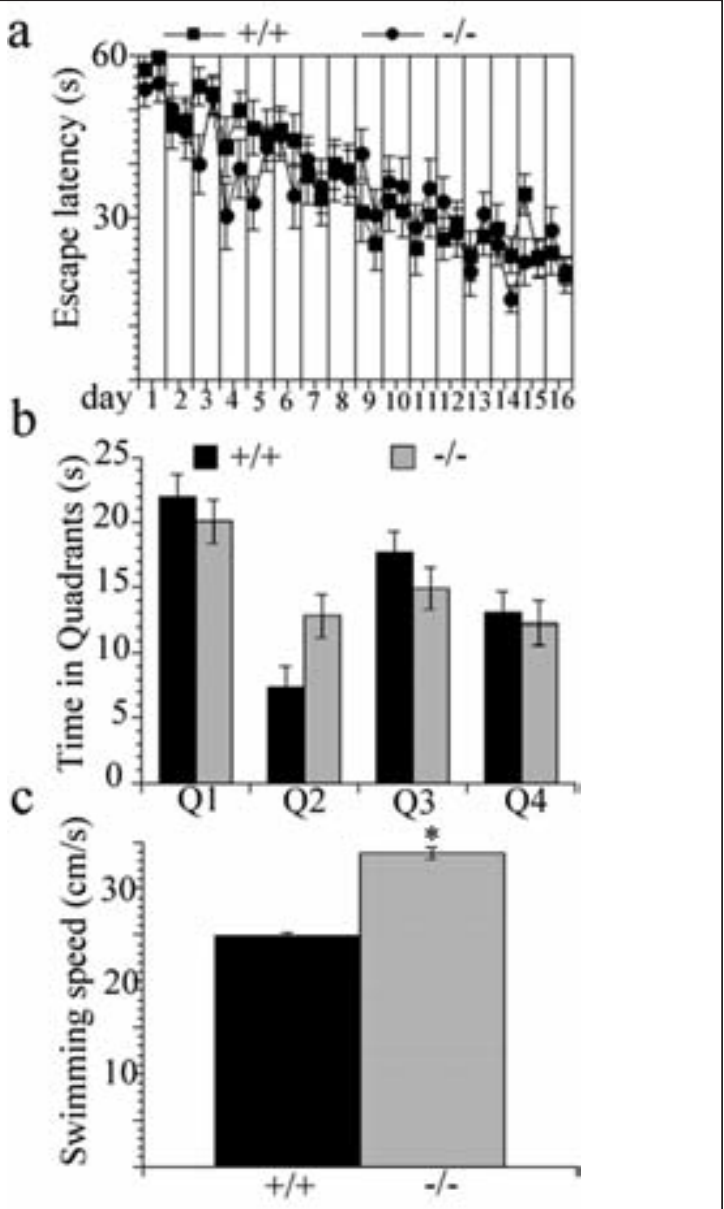

Figure 4: Faster swimming speed of Sema4D-deficient mice. Sema4Ddeficient mice showed normal spatial learning in Morris water maze tasks (a). Sema4D-deficient mice also showed normal spatial memory in the probe test in which the goal in quadrant $1(Q 1)$ was removed before the test $(b)$. Sema4D-deficient mice exhibited a significantly faster swimming speed than wild-type mice (c). +/+: wild-type; -/-: Sema4Ddeficient mice. ${ }^{*} p<0.05$, Student's t-test.

Sema4D during brain development may generate abnormal semaphorin signaling induced by compensatory upregulation of several semaphorins in basal ganglia or the cerebellum. As a result, abnormal neural development including increased synaptic growth or axonal overshooting may be generated in regions of the Sema4D-deficient brain, resulting in enhanced motor activity. Future extensive studies are needed to test these possibilities using detailed morphological studies and expression analyses of various semaphorins in the Sema4D-deficient brain. The absence of prepulse inhibition deficits in the acoustic startle reflex suggests that the enhanced motor activity of Sema4Ddeficient mice may not be derived from abnormal information processing, as often seen in animal psychiatric disease models ${ }^{26,27}$. It is further suggested that Sema4D-deficient mice may have anxiety-related behavior in the novel open field because of their preference to search around the periphery ${ }^{28}$.
However, their anxiety-related behavior was not so strong as to disturb their behavior in the elevated plus maze, light-dark exploration test and water-maze spatial learning. Thus, the anxiety-related behavior seen only in the novel open field may have partly accelerated hyperlocomotion of Sema4D-deficient mice. Sema4D-deficient mice tend to progressively develop autoimmune hepatitis and nephritis with age, and these diseases are mainly mediated by autoantibodies ${ }^{29}$. Antibody-mediated brain injury is known to initially occur in the mouse hippocampus, leading to the development of memory impairment ${ }^{30}$. Since Sema4D-deficient mice preserve normal memory in Morris water maze tasks and the novel recognition memory test, autoantibodies in these animals may not have crossed the blood-brain barrier ${ }^{31}$ or generated overt neuropsychiatric syndromes ${ }^{32-37}$ or memory impairment ${ }^{30}$. Another possibility may reside in muscular development, since several roles of semaphorins in the muscular system have been reported $^{38-40}$. Since the adhesive tape removal test requires coordinated forelimb use $\mathrm{u}^{41-44}$, subtle altered structures responsible for enhanced motor activity in Sema4D-deficient mice may reside in nigrostriatal regions or cerebellar nuclei rather than the muscular system ${ }^{45-48}$. Thus, the superior performance of Sema4D-deficient mice in the various motor behavior tests may be the first clue toward identifying the developmental step in which semaphorins are crucial for construction of the functional neuronal circuitry governing motor behavior in mice.

In conclusion, our study showed that inhibition of Sema4D activity from an early stage of mouse development results in facilitated motor activity in mouse behavior tests. Provided that regeneration partly recapitulates the developmental process, Sema4D and other semaphorin members may be potential tools in promoting nerve regeneration after CNS injury. It may therefore be possible to develop therapeutic approaches for CNS injury by modulating semaphorin activity ${ }^{18}$. Moreover, our results support the notion that Sema4D provides clues for development of new therapies against CNS injury.

\section{ACKNOWLEDGEMENTS}

The authors thank K. Kubota, M. Kishino, T. Ueyama and E. Yukawa for their encouragement and support. This study was partly supported by Grants-in-Aid for Scientific Research from the Ministry of Education, Science, Sports and Culture, Japan.

\section{REFERENCES}

1. Semaphorin Nomenclature Committee. Unified nomenclature for the semaphorins/collapsins. Cell. 1999;97(5):551-2.

2. Kapfhammer JP, Raper JA. Collapse of growth cone structure on contact with specific neurites in culture. J Neurosci. 1987;7(1): 201-12.

3. Nakamura F, Kalb RG, Strittmatter SM. Molecular basis of semaphorin-mediated axon guidance. J Neurobiol. 2000;44(2): 219-29.

4. Raper JA. Semaphorins and their receptors in vertebrates and invertebrates. Curr Opin Neurobiol. 2000;10(1):88-94.

5. Kruger RP, Aurandt J, Guan KL. Semaphorins command cells to move. Nat Rev Mol Cell Biol. 2005;6(10):789-800.

6. Tamagnone L, Comoglio PM. To move or not to move? Semaphorin signalling in cell migration. EMBO reports. 2004;5(4):356-61.

7. Swiercz JM, Kuner R, Behrens J, Offermanns S. Plexin-B1 directly interacts with PDZ-RhoGEF/LARG to regulate RhoA and growth cone morphology. Neuron. 2002;35(1):51-63. 
8. Oinuma I, Ishikawa Y, Katoh H, Negishi M. The semaphorin 4D receptor plexin-B1 is a GTPase activating protein for R-Ras. Science. 2004;305(5685):862-5.

9. Oinuma I, Katoh H, Negishi M. Semaphorin 4D/Plexin-B1mediated R-Ras GAP activity inhibits cell migration by regulating $\beta 1$ integrin activity. J Cell Biol. 2006;173(4):601-13.

10. Ito Y, Oinuma I, Katoh H, Kaibuchi K, Negishi M. Sema4D/plexinB1 activates GSK-3 $\beta$ through R-Ras GAP activity, inducing growth cone collapse. EMBO reports. 2006;7(7):704-9.

11. Paradis S, Harrar DB, Lin Y, Koon AC, Hauser JL, Griffith EC, et al. An RNAi-based approach identifies molecules required for glutamatergic and GABAergic synapse development. Neuron. 2007;53(2):217-32.

12. Shi W, Kumanogoh A, Watanabe C, Uchida J, Wang X, Yasui T, et al. The class IV semaphorin CD100 plays nonredundant roles in the immune system: defective B and T cells activation in CD100deficient mice. Immunity. 2000;13(5):633-42.

13. Glynn D, Drew CJ, Reim K, Brose N, Morton AJ. Profound ataxia in complexin 1 knockout mice masks a complex phenotype that includes exploratory and habituation deficits. Hum Mol Gent. 2005;14(16):2369-85

14. Boyce-Rustay JM, Holmes A. Genetic inactivation of the NMDA receptor NR2A subunit has anxiolytic- and antidepressant-like effects in mice. Neuropsychopharmacology. 2006;31(11): 2405-14.

15. Paylor R, Nguyen M, Crawley JN, Patrick J, Beaudet A, OrrUrtreger A. $\alpha 7$ nicotinic receptor subunits are not necessary for hippocampal-dependent learning or sensorimotor gating: a behavioral characterization of Acra7-deficient mice. Learn Mem. 1998;5(4-5):302-16.

16. Chen L, Cagniard B, Mathews T, Jones S, Koh HC, Ding Y, et al. Age-dependent motor deficits and dopaminergic dysfunction in DJ-1 null mice. J Biol Chem. 2005;280(22):21418-26.

17. Gard PR, Daw P, Mashhour ZS, Tran P. Interactions of angiotensin IV and oxytocin on behaviour in mice. J Renin Angiotensin Aldosterone Syst. 2007;8(3):133-8.

18. Moreau-Fauvarque C, Kumanogoh A, Camand E, Jaillard C, Barbin $\mathrm{G}$, Boquet I, et al. The transmembrane semaphorin Sema4D/ CD100, an inhibitor of axonal growth, is expressed on oligodendrocytes and upregulated after CNS lesion. J Neurosci. 2003:23(27):9229-39.

19. Worzfeld T, Püschel AW, Offermanns S, Kuner R. Plexin-B family members demonstrate non-redundant expression patterns in the developing mouse nervous system: an anatomical basis for morphogenetic effects of Sema4D during development. Euro J Neurosci. 2004;19(40):2622-32.

20. Fazzari P, Penachioni J, Gianola S, Rossi F, Eickholt BJ, Maina F, et al. Plexin-B1 plays a redundant role during mouse development and in tumour angiogenesis. BMC Dev Biol. 2007;7:55.

21. Morris RG. Place navigation impaired in rats with hippocampal lesions. Nature. 1982;297(5868):681-3.

22. Tamagnone L, Comoglio PM. Signaling by semaphorin receptors: cell guidance and beyond. Trends Cell Biol. 2000;10(9):377-83.

23. Barberis D, Artigiani S, Casazza A, Corso S, Giordano S, Love CA, et al. Plexin signaling hampers integrin-based adhesion, leading to Rho-kinase independent cell rounding, and inhibiting lamellipodia extension and cell motility. FASEB J. 2004;18(3): $592-4$

24. Kumanogoh A, Kikutani H. The CD100-CD72 interaction: a novel mechanism of immune regulation. Trends Immunol. 2001;22 (12):670-6

25. Furuyama T, Inagaki S, Kosugi A, Noda S, Saitoh S, Ogata M et al. Identification of a novel transmembrane semaphoring expressed on lymphocytes. J Biol Chem. 1996;271(52):33376-81.

26. Miyakawa T, Leiter LM, Gerber DJ, Gainetdinov RR, Sotnikova $\mathrm{TD}$, Zeng $\mathrm{H}$, et al. Conditional calcineurin knockout mice exhibit multiple abnormal behaviors related to schizophrenia. Proc Natl Acad Sci U S A. 2003;100(15):8987-92.

27. Clapcote SJ, Lipina TV, Millar JK, Mackie S, Christie S, Ogawa F, et al. Behavioral phenotypes of Disc1 missense mutations in mice. Neuron. 2007;54(3):387-402.
28. Holmes A, Yang RJ, Lesch KP, Crawley JN, Murphy DL. Mice lacking the serotonin transporter exhibit 5-HT(1A) receptormediated abnormalities in tests for anxiety-like behavior. Neuropsychopharmacology. 2003;28(12):2077-88.

29. Kumanogoh A, Shikina T, Watanabe C, Takegahara N, Suzuki K, Yamamoto M, et al. Requirement for CD100-CD72 interactions in fine-tuning of $\mathrm{B}$-cell antigen receptor signaling and homeostatic maintenance of the B-cell compartment. Int Immunol. 2005;17(10):1277-82.

30. Kowal C, DeGiorgio LA, Nakaoka T, Hetherington H, Huerta PT, Diamond B, et al. Cognition and immunity; antibody impairs memory. Immunity. 2004;21(2): 179-88

31. Kowal C, DeGiorgio LA, Lee JY, Edgar MA, Huerta PT, Volpe BT, et al. Human lupus autoantibodies against NMDA receptors mediate cognitive impairment. Proc Natl Acad Sci USA. 2006;103(52):19854-9.

32. Darnell RB, Posner JB. Paraneoplastic syndromes involving the nervous system. N Engl J Med. 2003;349(16):1543-54.

33. Edwards MJ, Trikouli E, Martino D, Bozi M, Dale RC, Church AJ, et al. Anti-basal ganglia antibodies in patients with atypical dystonia and tics: a prospective study. Neurology. 2004;63 (1):156-8

34. Fatemi SH. Reelin glycoprotein: structure, biology and roles in health and disease. Mol Psychiatry. 2005;10(3):251-7.

35. Kirvan CA, Swedo SE, Heuser JS, Cunningham MW. Mimicry and autoantibody-mediated neuronal cell signaling in Sydenham chorea. Nat Med. 2003;9(7):914-20

36. Padmos RC, Bekris L, Knijff EM, Tiemeier H, Kupka RW, Cohen $\mathrm{D}$, et al. A high prevalence of organ-specific autoimmunity in patients with bipolar disorder. Biol Psychiatry. 2004;56(7): 476-82.

37. Snider LA, Swedo SE. PANDAS: current status and directions for research. Mol Psychiatry. 2004;9(10):900-7.

38. Ko JA, Kimura Y, Matsuura K, Yamamoto H, Gondo T, Inui M. PDZRN3 (LNX3, SEMCAP3) is required for the differentiation of C2C12 myoblasts into myotubes. J Cell Sci. 2006;119(Pt 24): 5106-13.

39. Wu H, Wang X, Liu S, Wu Y, Zhao T, Chen X, et al. Sema4C participates in myogenic differentiation in vivo and in vitro through the p38 MAPK pathway. Eur J Cell Biol. 2007;86(6): 331-44.

40. Svensson A, Libelius R, Tågerud S. Semaphorin 6C expression in innervated and denervated skeletal muscle. J Mol Histol. 2008; 39(1):5-13

41. Whishaw IQ, Suchowersky O, Davis L, Sarna J, Metz GA, Pellis SM. Impairment of pronation, supination, and body coordination in reach-to-grasp tasks in human Parkinson's disease (PD) reveals homology to deficits in animal models. Behav Brain Res. 2002;133(2):165-76.

42. Montoya CP, Campbell-Hope LJ, Pemberton KD, Dunnett SB. The "staircase test": a measure of independent forelimb reaching and grasping abilities in rats. J Neurosci Methods. 1991;36(2-3): 219-28.

43. Barnéoud P, Parmentier S, Mazadier M, Miquet JM, Boireau A, Dubédat $\mathrm{P}$, et al. Effects of complete and partial lesions of the dopaminergic mesotelencephalic system on skilled forelimb use in the rat. Neuroscience. 1995;67(4):837-48.

44. Chang JW, Wachtel SR, Young D, Kang UJ. Biochemical and anatomical characterization of forepaw adjusting steps in rat models of Parkinson's disease: studies on medial forebrain bundle and striatal lesions. Neuroscience. 1999;88(2):617-28.

45. Graybiel AM, Aosaki T, Flaherty AW, Kimura M. The basal ganglia and adaptive motor control. Science. 1994;265(5180):1826-31.

46. Saint-Cyr JA, Taylor AE, Nicholson K. Behavior and the basal ganglia. Adv Neurol. 1995;65:1-28.

47. Ito M. The cerebellum and neural control. New York: Raven Press; 1984.

48. Thach WT, Goodkin HP, Keating JG. The cerebellum and the adaptive coordination of movement. Annu Rev Neurosci. 1992;15:403-42. 